\title{
Separating the Impacts of Climatic Variation and Human Activities on River Discharge of a Forest Watershed in North China
}

\author{
Yang Zhao ${ }^{1}$, Shengzhuo Hua ${ }^{2,3}$, Xiaoming Zhang ${ }^{1 *}$, Chen Cheng ${ }^{1}$, Bing Liu ${ }^{1}$ \\ ${ }^{1}$ State Key Laboratory of Simulation and Regulation of Water Cycle in River Basin, \\ China Institute of Water Resources and Hydropower Research, Beijing 100048, PR China \\ ${ }^{2}$ Beijing Forestry University, Beijing 100083, PR China \\ ${ }^{3}$ Soil and Water Conservation Plant Development and Management Center of the Ministry \\ of Water Resources, Beijing 100038, PR China
}

Received: 29 January 2015

Accepted: 7 March 2016

\begin{abstract}
There is convincing evidence that climatic variation and human activities are key factors impacting the hydrological behavior of a watershed. But little attention has been paid to such impacts on mesoscale and microscale forest basins, and key details remain unresolved. In this study, a small forest watershed in north China was selected as our study object. Separate evaluation and statistical methods were used to assess the impacts of climatic variation and human activities on changes in river discharge. The Mann-Kendal test indicated that annual rainfall did not vary significantly, whereas the annual river discharge decreased significantly at 99\% confidence interval during 1981-2011. Through separation evaluation, it was determined that climatic variation was the strongest contributor to changes in annual river discharge, with the average contribution reaching $66.8 \%$, while the remaining contributor was total human activities (33.2\%). The influence of various types of human activities on river discharge reduction is quite different. Forest recovery has a more positive impact on river discharge decrease, which accounts for about $89.24 \%$ of the discharge decrease caused by total human activities. Compared to the impact of climatic variation, it is inferred that large-scale forestation in this region may not be the main reason for the reductions in river discharge. Results provide important benchmarks for assessing the significance of afforestation on regional water resources, and also provide an objective assessment for improving future forestry development strategies in north China.
\end{abstract}

Keywords: climatic variability, afforestation, river discharge, separate evaluation method, north China

*e-mail: zwmwq@126.com 


\section{Introduction}

Water shortage and desertification of land are major environmental problems in north China and became particularly severe in the latter half of the 20th century as a result of several natural and anthropogenic causal factors. To control severe soil and water losses, largescale forestation programs have been implemented in the past few decades [1]. Indeed, over the past 20 years in particular, the large-scale forestation and construction of water conservancy projects in north China have brought major benefits to comprehensive control of soil erosion [2], but it has also caused serious concerns in water yield reduction [3]. Miyun reservoir, located in northeast Beijing, is a critical source of drinking water for the 14 million people living in this booming metropolis [4]. The inflow to the reservoir during the 1999 drought was reduced from a 400 to 800 million $\mathrm{m}^{3}$ (in years with average rainfall) to a mere 73 million $\mathrm{m}^{3}$ [5]. Reductions in the inflow from the mountains put tremendous pressure on sustainable socio-economic development, and received considerable attention - both from the Chinese government and researchers.

Climatic variation and human activities are the major forces behind hydrological variability by affecting the generation of runoff and soil moisture [6, 7]. Climatic variables, especially rainfall, largely determine the runoff hydrograph of a basin [8]. Human activities also can influence drainage basin features [9]. As a forest watershed, forest changes caused by human activities can affect the amount of river discharge through influence on evapotranspiration, infiltration, and flow timing over a range of temporal and spatial scales [10]. However, research on the relationship between forest changes and river discharge in meso-scale and micro-scale forest basins (e.g., $<100 \mathrm{~km}^{2}$ ) is rare, mainly because of the difficulty in distinguishing the influence of the complex interaction of various environmental factors on water yield. Moreover, with the rapid implementation of the afforestation project in north China, the contradiction between water supply and demand has become increasingly prominent, and water shortage has become a bottleneck to national economic development. Therefore, it is critical and urgent to understand the impacts of climatic variation and human activities on river discharge - especially the hydrological responses to forestation. Information about the forestation impacts on water yield is important for supporting the regional forestry development as countrywide reforestation programs are being implemented and concerns have arisen over possible water reduction in north China.

Research on the relationship between forests and streamflows has long been an important research topic in watershed hydrology [11]. Much progress has been made in understanding forests and associated water relations around the world [12-15]. However, the results for different scale watersheds are inconsistent. For example, Farley et al. (2005) using a variety of published data showing that annual water yield was reduced by 44 and
$31 \%$ when grasslands and shrublands, respectively, were afforested [16]. Lin and Wei (2008) studied the impact of forest harvesting on hydrology for a forest watershed and concluded that forest harvesting significantly increased mean annual runoff [17]. These studies mentioned above all indicated that forestation was primarily responsible for reducing basin water yield. In contrast, contradictory reports on the impact of forest on water yield also exist. For example, Ma (1993) concluded that basins with greater forest coverage generally had higher runoff coefficient through comparing streamflow from 10 large basins $(>100$ $\mathrm{km}^{2}$ ) in the Yangtze River basins [18]. Similar positive correlations between forests and water yield for large basins were reported for north China [19]. In summary, by referencing the previous research, it is easy to find that uncertainty and variability exist in the relationship between forestation on potential hydrologic responses across China due to the large differences in climate and watershed characteristics. Moreover, knowledge about the impacts of forestation on water yield clearly in north China is too limited to support regional forestry development and associated water resources management. Therefore, we examined a typical forest watershed in this region to determine the reason for the reduction of water yield from mountainous areas and provide an objective assessment of the effects of forestation on river discharge.

Research on the assessment of the forest-water yield relationship in forest watersheds is challenging mainly due to the lack of commonly accepted research methods [10]. The paired watershed approach to examining forestwater relations has been widely accepted in studying the immediate effects of deforestation and hydrologic recovery after harvesting. However, the lack of standard paired watershed experiments has impeded the development of forest hydrology research in China [11]. The hydrological models approach is useful and effective, but it is often constrained by a lack of data that may be unavailable, particularly spatial data representing the landscape structure and its catchment properties. Statistical approaches can be used to directly test the significant relationship between dependent and independent variables, but it may not lead to understanding the underlying mechanisms of the studied relations. In this study, we adopted a separate evaluation method with statistical approaches to explore the main reason for the reduction of annual river discharge in the typical forested watersheds of north China. Our research objectives of this paper are as follows:

1. To quantify the long-term trends in rainfall and river discharge at the whole watershed.

2. To assess the relative role of forests in influencing river discharge among many other variables.

\section{Materials and Methods}

\section{Study Area}

The Banchengzi watershed, located north of Miyun Reservoir, Beijing city, in north China, is one of the 


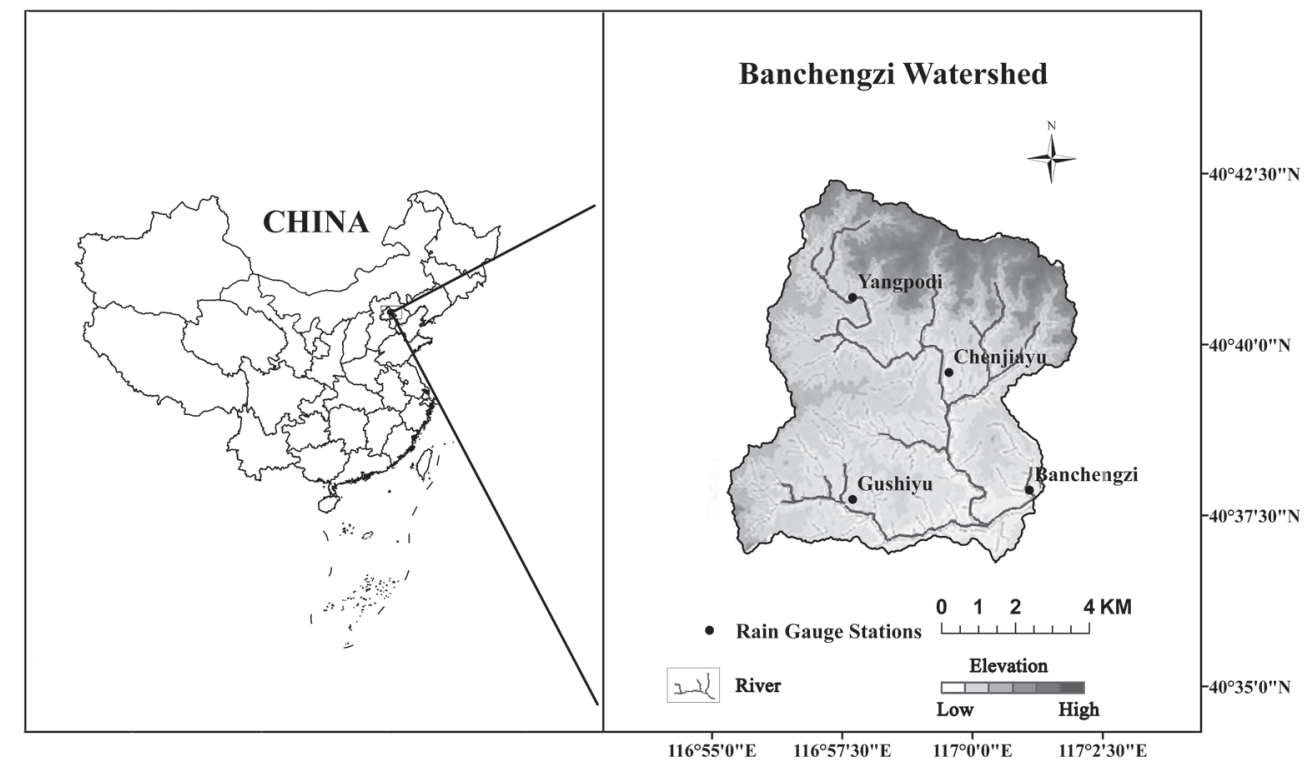

Fig. 1. Location of Banchengzi Watershed

tributaries of the Chaobai River watershed (Fig. 1). It has an area of approximately $66.1 \mathrm{~km}^{2}$, and lies between latitude $40^{\circ} 37^{\prime}$ and $40^{\circ} 43^{\prime} \mathrm{N}$ and longitude $116^{\circ} 55^{\prime}$ and $117^{\circ} 2^{\prime}$ E. Elevation in the watershed ranges from 250-1,200 $\mathrm{m}$, and annual rainfall ranges between $344-988 \mathrm{~mm}$. Average annual temperature is above $10.5^{\circ} \mathrm{C}$ and the area lies in the warm temperate zone with semihumid climate. Forest is the major land use type in the watershed, and the average forest cover rate has been above $90 \%$ for the past 30 years. Soil types are cinnamon and brown soil. No water conservation measures and industries exist in the watershed, which is beneficial to qualifying the relative role of forests in influencing river discharge (among many other variables).

\section{Data Collection}

\section{Land Use Change}

Five satellite images (Thematic Mapper) of the study watershed were obtained from the Institute of Geographic Sciences and Natural Resources Research, Chinese Academy of Science (CAS). Using ArcGIS9.3, land use structure and land cover changes of the watershed were obtained through overlay analysis. According to the national land-use classification system (2001), eight land uses such as shrub, coniferous forest, broadleaf forest, mixed-forest, farmland, grassland, urban, and water body were identified.

\section{Climatic Variations}

In this study, the daily rainfall data from four rain gauge stations were used to calculate annual rainfall $(R)$ and annual erosive rainfall in the Banchengzi watershed during 1981-2011. For the 31 years of records, no daily data were missed over the periods. Runoff generally occurred in a few erosive rainfall events that were short and intense [20]. Previous studies have indicated that 25.8 $\mathrm{mm}$ could be the standard for describing erosive rainfall in north China [21]. Hence, $25.8 \mathrm{~mm}$ of daily rainfall was used as the standard for erosive rainfall in our study, and annual erosive rainfall data were obtained from the daily rainfall data using a classifying sum during data processing with Microsoft Access. Air temperature and other meteorological factors, including relative humidity, solar radiation, and wind speed, were derived from Miyun County national weather stations.

\section{Realized Water Yield and Domestic Water Consumption}

Daily river discharge data during 1981-2011 were collected from the Hydrological Yearbook of Banchengzi River Watershed (unpublished data, 2013). The river discharge coefficient is calculated based on measured river discharge and rainfall. Domestic water consumption (DWC) recommended by Zhao (2013) was computed as [22]:

$$
\begin{aligned}
D W C=\left(N_{U} \times Q_{U}\right. & +N_{R} \times Q_{R}+N_{S L} \times Q_{S L}+N_{L L} \times \\
& \left.\times Q_{L L}\right) \times 365
\end{aligned}
$$

...where $D W C$ is domestic water consumption (Unit: 1), $N_{U}$ and $N_{\mathrm{R}}$ represent urban and rural populations, $Q_{\mathrm{U}}$ and $Q_{\mathrm{R}}$ are average water demands of urban and rural populations per person per day $(1 / \mathrm{p} / \mathrm{d}), N_{\mathrm{SL}}$ and $N_{\mathrm{LL}}$ are the number of small livestock (pigs, sheep, chickens, and ducks) and large livestock (cattle, horses, mules and 
Table 1. Average water demand in the watershed.

\begin{tabular}{|c|c|c|c|c|c|c|}
\hline \multirow{2}{*}{ Period } & \multirow{2}{*}{$\begin{array}{c}\text { Rural } \\
(1 / \mathrm{p} / \mathrm{d})\end{array}$} & \multirow{2}{*}{$\begin{array}{c}\text { Big livestock } \\
(1 / \text { head/d) }\end{array}$} & \multicolumn{4}{|c|}{ Small livestock $(1 /$ head/d) } \\
\cline { 4 - 7 } & 105 & 40 & pig & duck & sheep & chicken \\
\hline $1981-98$ & 268 & 40 & 20 & 1.5 & 5 & 1 \\
\hline $1999-2011$ & & 1.5 & 5 & 1 \\
\hline
\end{tabular}

Table 2. Populations and breeding industry structure statistics.

\begin{tabular}{|c|c|c|c|c|c|c|c|c|c|}
\hline Year & Rural & Cattle & Horses & Mules & Donkeys & Pigs & Sheep & Chickens & Ducks \\
\hline 1996 & 3924 & 434 & 7 & 36 & 164 & 6196 & 2090 & 6464 & 385 \\
\hline 2006 & 3560 & 799 & 0 & 7 & 48 & 5179 & 5770 & 42229 & 1508 \\
\hline
\end{tabular}

donkeys), and $Q_{\mathrm{SL}}$ and $Q_{\mathrm{LL}}$ are the average water demand of small livestock and large livestock per head per day (1/p/d). Water consumption cited by Ma and Zheng (2006) is shown in Table 1 [23]. Watershed populations and livestock numbers are listed in Table 2.

Considering that no water conservation measures and industries exist in the study watershed, $D W C$ is mainly the outflow of river discharge $(R D)$. Hence, the realized water yield $(R W Y)$ in the Banchengzi watershed can be calculated as follows:

$$
R W Y=R D+D W C
$$

\section{Statistical Tests for Trends}

The nonparametric Mann-Kendall (M-K) test has been widely used to test trends in climatology and hydrology $[24,25]$. In this study, it was employed to detect trends in climatic factors and annual mean realized water yield $(R W Y)$ over the observation period. The non-parametric Sen's method, which has been called the most popular nonparametric technique for estimating a linear trend, was applied to detect the magnitude of slope changes in $R, T, R W Y$, and $R W Y / R$. The non-parametric, robust estimate of the magnitude of slope $\beta$ is determined by Islam et al. (2015) [26]. Moreover, to further analyze the effect of different climate elements on river discharge, the normalization method was applied to detect trends of $R W Y$ and climatic variables, and the normalized index $(N I)$ can be calculated as follows [27]:

$$
N I=(x \text {-MinValue }) /(\text { MaxValue-MinValue })(3)
$$

...where $x$ is the value before transformation, and MinValue and MaxValue are the minimum and maximum value of the data series.

\section{Variables Affecting River Discharge Changes}

From a regional water cycling perspective, because a reservoir and no industries exist in the study forest watershed, river discharge variation is usually influenced by rainfall, evapotranspiration, human water consumption, and forest changes. Human water consumption is the total net water consumption used for rural living, farmland irrigation, and livestock water. To explore variables affecting river discharge changes, the separation evaluation method was used to examine the impacts of climatic variability and human activities on river discharge. This method has been proved to be applicable in north China [28-30]. According to the ideas of Separation evaluation method, we assumed that change in river discharge $\left(\Delta R_{\text {total }}\right)$ is mainly influenced by climatic variation $\left(\Delta R_{\text {climate }}\right)$ and human activities $\left(\Delta R_{\text {human }}\right)$ and it can be estimated by the following equation:

$$
\Delta R_{\text {total }}=\Delta R_{\text {climate }}+\Delta R_{\text {human }}
$$

As mentioned earlier, climatic variability is represented by changes in potential evapotranspiration (PET) and $R$, while human activities include forest changes and water consumption (e.g., water uses for rural living and livestock water). To quantify the relative contribution of these variables to river discharge changes, first the M-K test was applied to detect trends in annual realized river discharge. If there was a significant trend, further analyses were performed using both double mass curve and t-test to determine inflection point(s). An inflection in the slope of the curve would indicate that the hydrological series is significantly altered at one period but not at the other [31]. If there was an inflection point, the annual realized river discharge study period was divided into two periods: a baseline period and a comparison period, and further analysis were performed only on hydrological series for the comparison period after the inflection point.

Second, for the comparison period, the effects of human activities on annual river discharge $\left(\Delta R_{\text {human }}\right)$ can be quantified by removing the effects of climatic variability $\left(\Delta R_{\text {climate }}\right)$ from total river discharge variation $\left(\Delta R_{\text {total }}\right)$. $\Delta R_{\text {climate }}$ may be determined by Milly and Dunne [32]:

$$
\Delta R_{\text {climate }}=\beta \Delta R+\gamma \Delta P E T
$$


...where $\triangle R$ and $\triangle P E T$ are changes in annual rainfall and $P E T$ (mm), respectively, and $\beta$ and $\gamma$ are the river discharge sensitivity coefficients to $\triangle R$ and $\triangle P E T$, respectively. $\boldsymbol{P E T}$ was estimated for the whole period of 1981 to 2011 through the method recommended by Priestley and Taylor [33].

According to Zhang et al. (2001) [34], sensitivity coefficients can be estimated by:

$$
\begin{gathered}
\beta=\frac{1+2 x+3 w x^{2}}{\left(1+x+w x^{2}\right)^{2}} \\
\gamma=-\frac{1+2 w x}{\left(1+x+w x^{2}\right)^{2}}
\end{gathered}
$$

...where $x$ is the index of dryness and equal to $P E T / R$ and $w$ is the plant-available water coefficient and represents the relative differences of water use for transpiration. Our previous studies calibrated the $w$ parameter, and found that $w$ coefficients were 1.5 for grass and farmland, 2.8 for forests, and 0 for a water body, and settlements provided the best predictions of actual evapotranspiration in north China [29].

Finally, once the effects of human activities $\left(\Delta R_{\text {human }}\right)$ on river discharge are known, we can then estimate the effect of forest coverage change $\left(\Delta R_{\text {forest }}\right)$ on river discharge by deducting the effects of other human activities (water consumption). $\Delta R_{\text {forest }}$ can be estimated by the following equation:

$$
\Delta R_{\text {forest }}=\Delta R_{\text {human }}-\Delta R_{\text {water consumption }}
$$

...where $\Delta R_{\text {water consumption }}$ is human water consumption in the study watershed ( $\mathrm{mm})$.

\section{Results}

\section{Variability of $R, P E T, R W Y$, and $R W Y / R$}

Average annual rainfall in Banchengzi watershed was $632.3 \mathrm{~mm}$, ranging from 344 to $988 \mathrm{~mm}$. The M-K test revealed that no significant trends in annual rainfall were detected for the study period 1981-2011( $Z=-1.33)$ (Table 3), although rainfall displayed an annual reduction of $5.11 \mathrm{~mm} /$ year, with a high annual variation of coefficient (CV) of 0.25 (Fig. 2). PET showed an overall trend of increase before 2007, reached a peak in 2007, and then fluctuated up and down until $2011\left(P>0.05, Z=1.89<\mathrm{Z}_{0.05}\right.$ $=1.96, \mathrm{CV}=0.11)$ (Table 3$)$. Under the influence of human activities and warmer and drier climates, $R W Y$ showed a significant decreasing trend, with an annual reduction of $5.84 \mathrm{~mm} /$ year $(P<0.01, Z=-2.72, \mathrm{CV}=1.21)$ during the study period. $R W Y / R$ also showed a significant decreasing trend $(Z=-2.55, P<0.01)$. From the double mass curve (a plot of cumulative annual rainfall against annual cumulative realized water yield), an inflection point (year 1998) was apparent, indicating that annual realized water yield decreased in 1998 (Fig. 3). Independent samples t-test was applied to test the significance of the changes of annual realized water yield before and after 1998, and indicated that discharge before and after 1998 varied significantly at a $95 \%$ confidence level $(t=3.65$, $d f=19.15, P=0.002<0.05)$. To further analyze the effect of climatic variation and total human activities on $R W Y$, average rainfall and realized water yield during the two periods in Banchengzi watershed are compared in Table 4.

\section{Land Use and Land Cover Changes}

Based on ArcGIS 9.3, the land use and land cover (LULC) of different periods were identified (Fig. 4). A comparison of land use and land cover maps for the years 1980, 1990, 2000, and 2010 indicates that forest are the main land use types in the Banchengzi watershed. Specifically, forest accounted for $88.90 \%$ of the Banchengzi watershed in 1980, while the figure was $96.75 \%$ in 2010 . The most significant changes occurred in two land use and land cover classes: coniferous forest and shrub land. The proportional area of coniferous forest increased from $27.03 \%$ to $41.03 \%$ from 1980 to 2010 . Conversely, shrub decreased from $36.55 \%$ to $6.35 \%$ in the same period. Moreover, from 1980 to 2010, the area of grassland, farmland and water body decreased from $8.46 \%$ to $1.53 \%$, from $0.61 \%$ to $0.15 \%$, and from $1.56 \%$ to $0.73 \%$, respectively, and the urban area increased from $0.47 \%$ to $0.84 \%$. Overall, the vegetation cover in the study watershed is high, which is mainly attributed to the longtime attention to the ecological construction of a water source area.

\section{Effects of Climatic Variations and Human Activities}

Using the year 1998 as a breakpoint and based on the calculation procedure described in section 2 , we estimated

Table 3. Mann-Kendall test statistics for climatic variables in the Banchengzi watershed for the period 1981-2011.

\begin{tabular}{|c|c|c|c|c|}
\hline Variable & Rainfall & $\begin{array}{c}\text { Potential } \\
\text { evapotranspiration }\end{array}$ & River discharge & River discharge/ Rainfall \\
\hline M-K test, $Z$ & -1.33 & 1.89 & $-2.72^{* * *}$ & $-2.55^{* *}$ \\
\hline Sen's slope, $\beta$ & -5.11 & 4.99 & -5.84 & -0.01 \\
\hline
\end{tabular}

$*, * *$, and $* * *$ indicate trends at $\alpha=0.1,0.05$, and 0.01 levels of significance, respectively. 

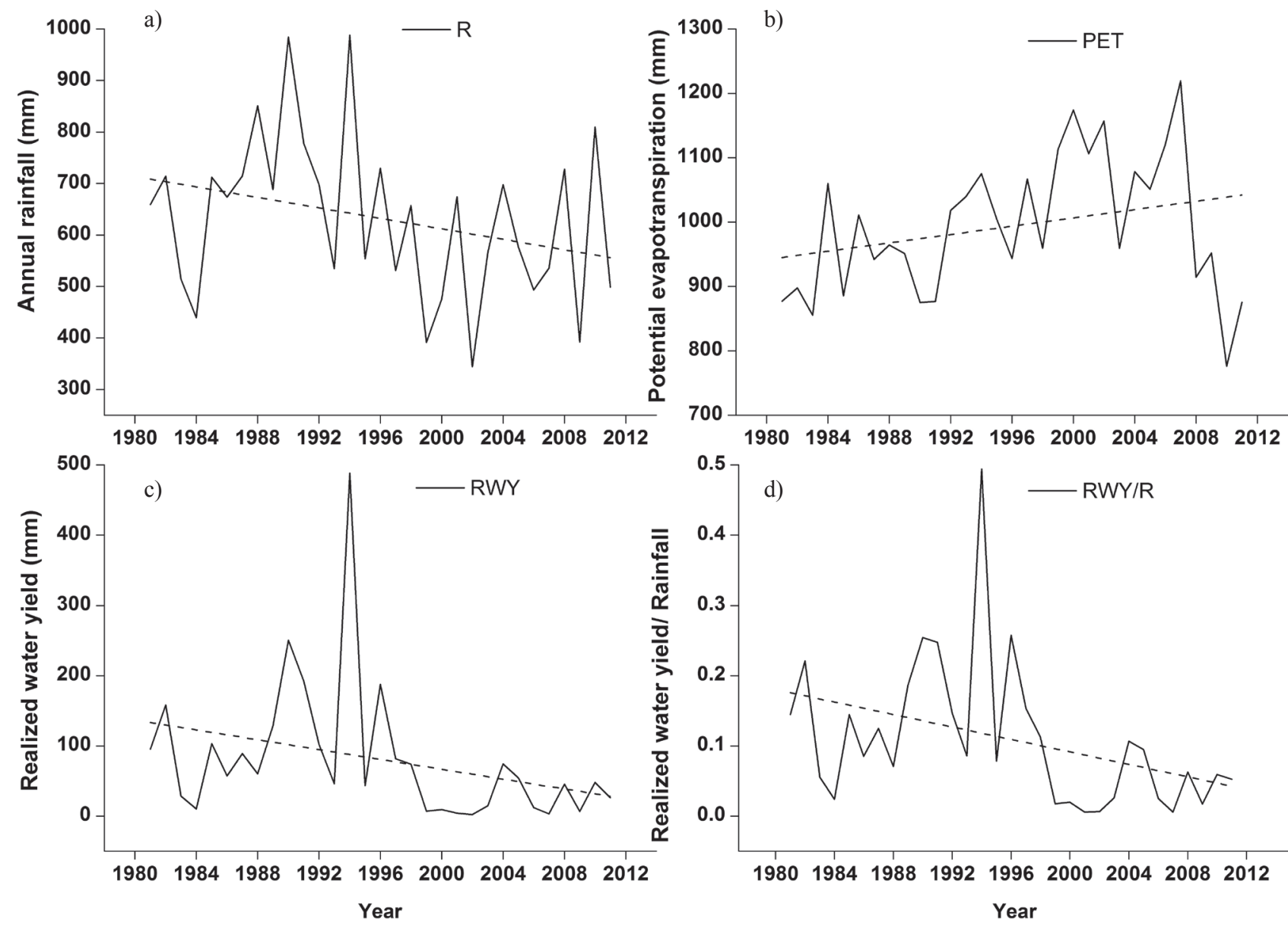

Fig. 2. Trends in: a) rainfall, b) potential evapotranspiration, c) realized water yield and d) ratios of realized water yield to rainfall from 1981 to 2011.

that the effect of climatic variations and total human activities on $R W Y$ is $5.05 \mathrm{~mm}$ and $2.51 \mathrm{~mm}$ annually for the period 1999-2011 (Table 5). Climate variation and total human activities account for $66.8 \%$ and $33.2 \%$ of the total river discharge decrease, respectively. Therefore, it

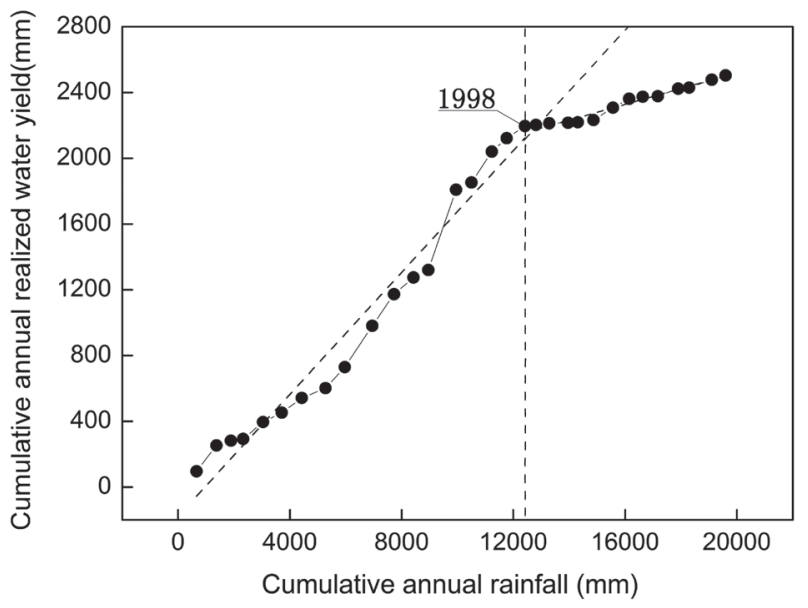

Fig. 3. Double mass curve between cumulative annual rainfall and cumulative annual realized water yield from 1981 to 2011. is inferred that climate variation is the main driving force of $R W Y$ reduction over the Banchengzi watershed in the past 31 years.

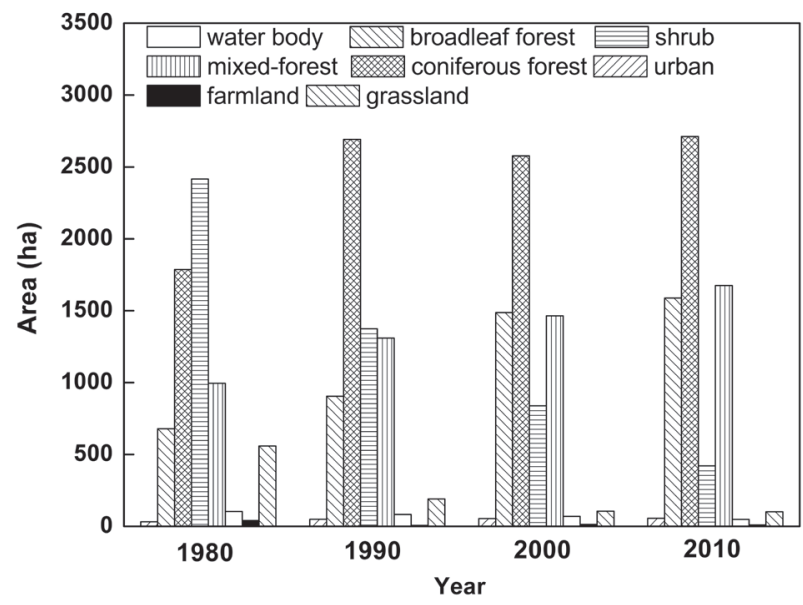

Fig. 4. Area of different land use/land cover types in 1980, 1990, 2000 and 2010 , respectively. 


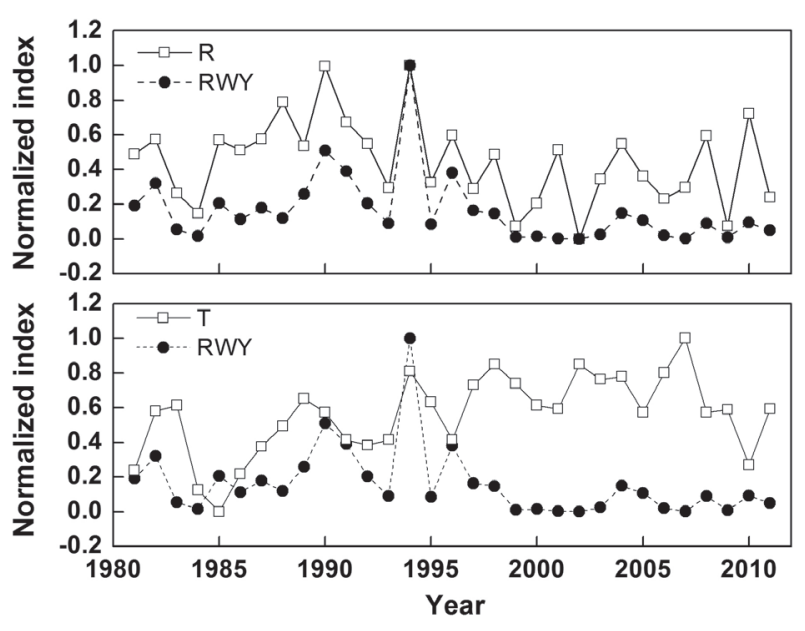

Fig. 5. Changes process of rainfall, temperature and realized water yield normalized.

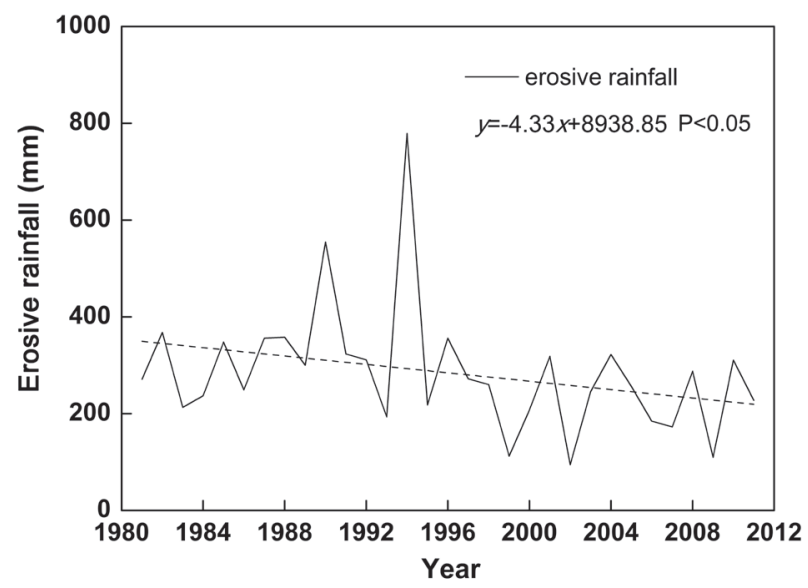

Fig. 6. Trends in erosive rainfall from 1981 to 2011.

\section{Discussion}

\section{Effects of Different Climate Factors}

As shown in section 3, climatic variations were identified as the strongest contributors $(66.8 \%)$ for the change in $R W Y$ from 1981 to 2011, compared with total human activities. However, there are a lot of climate factors (e.g., rainfall, temperature, etc.), and key factors remain unresolved. The normalization method was applied to further analyze the impact of $R$ and temperature $(T)$ on $R W Y$, and found that changes in $R W Y$ and $R$ were similar, which indicates the change of $R$ had a greater influence on $R W Y$ than $T$ (Fig. 5) in the study watershed. This finding is consistent with some related watershed studies in north China [35-37]. Further, as mentioned above, the M-K test did not detect a significant decrease trend in $R$, and trends in rainfall patterns may be responsible for the $R W Y$ decrease. Fig. 6 shows that annual erosive rainfall displays a significant decrease trend during the study period $(Z=-2.12, P<0.05 y=-4.33 x+8938.85$, where $x$ represents 1981-2011 and $y$ represents erosive rainfall), indicated that reductions of river discharge in the later period of 1999-2011 was judged to be caused by the greater decrease in extreme rainfall.

\section{Effects of Different Forms of Human Activity}

Taking into account the fact that no soil and water conservation engineering measures and major industrial or irrigation facilities exist in the Banchengzi watershed, LULC change caused by the forestation project and domestic water consumption from natural rainfall and groundwater were regarded as significant reasons for river discharge reduction.

\section{Effect of Variations of Annual Water Consumption}

Annual water consumption by humans and livestock in the studied watershed was calculated based on Eq. (1) (Table 4). Table 4 shows that the average annual water consumption in the two periods are $2.04 \times 10^{5} \mathrm{~m}^{3}$ and $4.33 \times 10^{5} \mathrm{~m}^{3}$, respectively. The average annual water consumption increases by $2.29 \times 10^{5} \mathrm{~m}^{3}$, which accounts for $0.27 \pm 0.12 \mathrm{~mm}$ annually during 1981-2011 (Table 5). This accounts for about $10.76 \%$ of the discharge decrease caused by total human activities, suggesting that variations of annual water consumption play a minor negative role in the reduction of river discharge in the Banchengzi watershed.

\section{Effect of Forest Recovery}

Combined with the results of the effects of variations of annual water consumption on $R W Y$, it is determined that the impact of forest coverage increases caused a total of $2.24 \pm 1.21 \mathrm{~mm}$ river discharge decrease from 1981 to 2011. This accounts for about $89.24 \%$ of the discharge decrease caused by total human activities, suggesting that forest recovery plays a major negative role in the reduction of river discharge in the Banchengzi watershed. This finding is consistent with some studies in north China [7]. The explanation for water reduction due to

Table 4. Average rainfall and RWY during the two periods in the Banchengzi watershed.

\begin{tabular}{|c|c|c|c|c|}
\hline Period & $\begin{array}{c}\text { Average rainfall } \\
(\mathrm{mm} / \text { year })\end{array}$ & $\begin{array}{c}\text { Average } R W Y \\
(\mathrm{~mm} / \mathrm{year})\end{array}$ & $\begin{array}{c}\text { Average forest cover rate } \\
(\%)\end{array}$ & $\begin{array}{c}\text { Average domestic water consumption } \\
\left(\mathrm{m}^{3} / \text { year }\right)\end{array}$ \\
\hline $1981-1998$ & 689.91 & 121.99 & 93.43 & $2.04 \times 10^{5}$ \\
\hline $1999-2011$ & 552.53 & 23.69 & 96.76 & $4.33 \times 10^{5}$ \\
\hline
\end{tabular}


Table 5. Average respective contributions of the effects of climatic variations and human activities on river discharge.

\begin{tabular}{|c|c|c|}
\hline Components & $\begin{array}{c}\text { Contribution } \\
(\mathrm{mm} / \mathrm{yr})\end{array}$ & $\begin{array}{c}\text { Contribution rate } \\
(\%)\end{array}$ \\
\hline $1 . \Delta \mathrm{R}_{\text {total }}$ & -7.56 & 100 \\
\hline $2 . \Delta R_{\text {climate }}$ & $-5.05 \pm 3.64$ & 66.80 \\
\hline $3 . \Delta R_{\text {human }}$ & $-2.51 \pm 2.05$ & 33.20 \\
\hline $3.1 \Delta R_{\text {forest }}$ & $-2.24 \pm 1.21$ & $22.93(89.24)$ \\
\hline $3.2 \Delta R_{\text {water consumption }}$ & $-0.27 \pm 0.12$ & $3.57(10.76)$ \\
\hline
\end{tabular}

reforestation is that actual evapotranspiration is increased after forests are increased due to increases in root systems and leaf areas, and lengthen the flow paths to rivers, so less water becomes river discharge. Combining the result of impact of climatic variation on river discharge, we reckoned that afforestation was not the main driving force for the reduction of river discharge in the Banchengzi watershed over the past 31 years. This conclusion is important because Beijing is continuously implementing reforestation programs and there are serious concerns over water reduction due to reforestation.

\section{Conclusions}

A separate evaluation method with statistical approaches was applied to assess the effects of climatic variation and different human activities on the changes of river discharge in the Banchengzi watershed in north China based on hydrological data over 30 years. On the basis of analysis results of variables affecting runoff changes, we concluded that climatic variations have a significant negative impact on the reduction in mean annual river discharge of the Banchengzi watershed, and the contribution rate reached $66.8 \%$ while the remainder was caused by human activities. This study also revealed that the influence of various types of human activities on water yield reduction is quite different, and the contribution of forest recovery to the decrease in river discharge is $22.93 \%$. Therefore, it is inferred that climate variations are the main cause of runoff decrease over the Banchengzi watershed in the study period.

Our study also demonstrates that although afforestation was not the main reason for the river discharge decrease, large-scale forestation efforts must be considered as impacting hydrological processes, because that afforestation will likely reduce the water yield and consequently threaten the regional water supply and sustainable development.

\section{Acknowledgements}

This research was financially supported by the National Natural Science Foundation of China (Nos. 41501041 and 51379008).

\section{References}

1. HE B., MIAO L., CUI X., WU Z. Carbon sequestration from China's afforestation projects. Environ. Earth Sci. 74 (7), 1-9, 2015

2. JIAN S., ZHAO C., FANG S., YU K. Effects of different vegetation restoration on soil water storage and water balance in the Chinese Loess Plateau. Agric. For. Meteorol. 206, 85, 2015

3. WANG Y., WEI X., STEPHAN G., ANDREW C.N., YU P., XU L. A Water yield-oriented practical approach for multifunctional forest management and its application in dryland regions of China. J. Am. Water Resour. As. 51 (3), 689, 2015.

4. LI X.S., WU B.F., ZHANG L. Dynamic Monitoring of Soil Erosion for Upper Stream of Miyun Reservoir in the Last 30 Years. J. Mt. Sci. 10 (5), 801, 2013.

5. PEISERT C., STERNFELD E. Quenching Beijing's Thirst: The Need for Integrated Management for the Endangered Miyun Resevoir. China Environment Series. 7, 33, 2005.

6. TOMER M.D., SCHILLING K.E. A simple approach to distinguish land-use and climate-change effects on watershed hydrology. J. Hydrol. 376 (1), 24, 2009.

7. WANG S., FU B.J., HE C.S. A comparative analysis of forest cover and catchment water yield relationships in North China. Forest Ecol. Manag. 262, 1189, 2011.

8. WANG G.S., XIA J., CHEN J. Quantification of effects of climate variations and human activities on runoff by a monthly water balance model: A case study of the Chaobai River basin in North China. Water Resour. Res. 45, W00A11, 2009.

9. WANG S., YAN Y., YAN M., ZHAO X. Contributions of precipitation and human activities to the runoff change of the Huangfuchuan drainage basin: application of comparative method of the slope changing ratio of cumulative quantity. Acta Geographica Sinica. 67 (3), 388, 2012 [In Chinese].

10. ZHOU G.Y., WEI X.H., LUO Y., ZHANG M.F., LI Y.L., QIAO Y.N. Forest recovery and river discharge at the regional scale of Guangdong Province, China. Water Resour. Res. 46 (9), W09503, 2010.

11. WEI X.H., SUN G., LIU S.R., ZHOU G.Y., DAI L. The forest-streamflow relationship in China: a 40-years retrospect. J. Am. Water Resour. As. 44 (5), 1076, 2008.

12. NIE W., YUAN Y., KEPNER W., NASH. S.M., JACKSON M., ERICKSON C. Assessing impacts of Land use and Land cover changes on hydrology for the upper San Pedro watershed. J. Hydrol. 407 (1), 105, 2011.

13. WANG Y.H., YU P.T., FEGER K.H., WEI X.H., SUN G., BONELL M. Annual runoff and evapotranspiration of forestlands and non-forestlands in selected basins of the Loess Plateau of China. Ecohydrology. 4 (2), 277, 2011.

14. BUENDIA C., BUSSI G., TUSET J., VERICAT D., SABATER S., PALAU A., BATALLA R.J. Effects of afforestation on runoff and sediment load in an upland Mediterranean catchment. Sci. Total Environ. 540, 144, 2015.

15. XIE X, LIANG S, YAO Y, JIA K., MENG S., LI J. Detection and attribution of changes in hydrological cycle over the Three-North region of China: Climate change versus afforestation effect. Agric. For. Meteorol. 203, 74, 2015.

16. FARLEY K.A., JOBBAGY E.G., JACKSON R.B. Effects of forestation on water yield: a global synthesis with implications for policy. Global Change Biol. 11, 1565, 2005.

17. LIN Y., WEI X. The impact of large-scale forest harvesting on hydrology in the Willow watershed of Central British Columbia. J. Hydrol. 359, 141, 2008. 
18. MAX. Forest Hydrology. China Forestry Publication House: Beijing, 28, 1993.

19. WEI X.H., LI W.H., ZHOU G.Y., LIU S.R., SUN G. Forests and Streamflow-Consistence and Complexity. Journal of Natural Resources. 20, 761, 2011 [In Chinese].

20. ANGULO-MARTINEZ M., BEGUERIA S. Estimating rainfall erosivity from daily rainfall records: a comparison among methods using data from the Ebro Basin (NE Spain). J. Hydrol. 379, 111, 2009.

21. LV X.Z. Study on the effect of forest vegetation on hydrological process on slope. Beijing Forestry University: Beijing, 58, 2013.

22. ZHAO Y., YU X. Effects of climatic variability and human activity on runoff in the Loess Plateau of China. Forest. Chron. 89 (2), 153-161, 2013.

23. MA Z.G., ZHENG D.W. Estimation of Rain-collection Amount and Water Utility in a Courtyard in the Ecotone of North Loess Plateau. Research of Soil and Water Conservation. 13 (5), 235-237, 2006 [In Chinese].

24. RAHMANI V., HUTCHINSON S.L., JR J.A.H., HUTCHINSON J.M.S., ANANDHI A. Analysis of temporal and spatial distribution and change - points for annual precipitation in Kansas, USA. Malaysian Journal of Pathology. 35 (13), 3879, 2015.

25. HAMED K.H. Exact distribution of the Mann-Kendall trend test statistic for persistent data. J. Hydrol. 365, 86, 2009.

26. ISLAM M.N., ALMAZROUI M., DAMBUL R., JONES P.D., ALAMOUDI A.O. Long-term changes in seasonal temperature extremes over Saudi Arabia during 1981-2010. Int. J. Climatol. 35 (7), 1579, 2015.

27. Baidu Inc. (undated). Baidubaike: Converting Linear Equations [online]. Available athttp://baike.baidu.com/ view/829823.htm, 2014.

28. ZHANG S.L., WANG Y.H., YU P.T. ZHANG H.J., TU X.W. Study for separating the impact of precipitation variation and human activities on runoff change of the Upper Reaches of Jing River. J. Soil Water Conserv. 24 (4), 53, 2010.

29. ZHAO Y., YU X.X., ZHENG J.K., WU Q.Y. Quantitative effects of climate variations and land-use changes on annual stream flow in Chaobai river basin. Transactions of the Chinese Society of Agricultural Engineering. 28 (22), 252, 2012 [in Chinese].

30. WANG Z.H., LI C.Z., YU F.L., XU Z.H., ZHAO N.N. Quantitative Analysis of The Effect of Climate Change and Human Activities on Stream flow. Journal of University of Jinan. 28 (4), 295, 2014.

31. BI H.X., LIU B., WU J., YUN L., CHEN Z.H., CUI Z.W. Effects of precipitation and landuse on runoff during the past 50 years in a typical watershed in Loess Plateau, China. Int. J. Sediment Res. 24, 352, 2009.

32. MILLY P.C.D., DUNNE K.A. Macroscale water fluxes 1. Quantifying errors in the estimation of basin mean precipitation. Water Resour. Res. 38 (10), 23-1-23-14, 2002.

33. PRIESTLEY C.H.B., TAYLOR R.J. On the assessment of the surface heat flux and evapotranspiration using large-scale parameters. Mon. Weather Rev. 100, 81, 1972.

34. ZHANG L., DAWES W.R., WALKER G.R. Response of mean annual evapotranspiration to vegetation changes at catchment scale, Water Resour. Res. 37 (3), 701, 2001.

35. WANG G.Q., ZHANG J.Y., LIU J.F., JIN J.L., LIU C.S. The sensitivity of runoff to climate change in different climatic regions in China. Advances in Water Science. 22 (3), 307, 2011 [In Chinese].

36. CHENG L.F., WANG H.Y. Sensitivity of Runoff to Climate Change in Small Drainage Basins in China. Resour. Sci. 26 (6), 62, 2004.

37. ZHAO Y., JIA J.B., TU Z.H. Estimating the sensitivity of annual runoff to climate change across a small forest basin in North China. Vegetos. 27 (2), 64, 2014. 